\title{
Correction to: Revealing the full ocean migration of individual Atlantic salmon
}

\author{
John Fredrik Strøm ${ }^{1 *}$, Eva Bonsak Thorstad ${ }^{2}$, Richard David Hedger ${ }^{2}$ and Audun Håvard Rikardsen 1,3
}

\section{Correction to: Anim Biotelemetry (2018) 6:2 https://doi.org/10.1186/s40317-018-0146-2}

In the online version of the original publication [1], there is an error in the caption of figure 8. The correct version can be found below.

\section{Incorrect version:}

Figure 8 Monthly diving depth for six tagged Atlantic salmon, with median diving depths given as solid lines, and whiskers representing the first and third quartile. Mean diving depths are given as green diamonds. Depth of the mixed layer is superimposed as a solid grey line (tag IDs are given above plot panels).

Correct version:

Figure 8 Monthly diving depths for six tagged Atlantic salmon, with median diving depths given as solid lines, and boxes representing the first and third quartiles. Mean diving depths are given as green diamonds. Depth of the mixed layer is superimposed as a solid grey line (tag IDs are given above plot panels).

\begin{abstract}
Author details
${ }^{1}$ Department of Arctic and Marine Biology, UiT The Arctic University of Norway, 9037 Troms $\varnothing$, Norway. ${ }^{2}$ Norwegian Institute for Nature Research (NINA), Høgskoleringen 9, 7034 Trondheim, Norway. ${ }^{3}$ Norwegian Institute for Nature Research (NINA), Framsenteret, 9007 Tromsø, Norway.
\end{abstract}

The original article can be found online at https://doi.org/10.1186/ s40317-018-0146-2.

\section{Publisher's Note}

Springer Nature remains neutral with regard to jurisdictional claims in published maps and institutional affiliations.

Published online: 14 June 2018

\section{Reference}

1. Strøm JF, Thorstad EB, Hedger RD, Rikardsen AH. Revealing the full ocean migration of individual Atlantic salmon. Anim Biotelem. 2018;6:2. https:// doi.org/10.1186/s40317-018-0146-2.

\footnotetext{
*Correspondence: john.f.strom@uit.no

${ }^{1}$ Department of Arctic and Marine Biology, UiT The Arctic University

of Norway, 9037 Tromsø, Norway

Full list of author information is available at the end of the article
} 